Piotr Pilarczyk

Uniwersytet im. Adama Mickiewicza w Poznaniu

https://doi.org/10.18778/8220-584-8.05

\title{
Trybunat Koronny i jego palestra w powieści Maleparta J. I. Kraszewskiego
}

\begin{abstract}
Streszczenie
Maleparta ze względu na podjętą tematykę jest utworem szczególnym w twórczości Józefa Ignacego Kraszewskiego. Tytułowym bohaterem powieści jest mecenas, który patronuje w lubelskim Trybunale Koronnym. Jego niebywała kariera adwokacka jest możliwa nie tylko dzięki prawniczym umiejętnościom, ale również odrażającym i niemoralnym praktykom. Kraszewski w powieści połączył lubelską legendę $\mathrm{z}$ dostępną sobie wiedzą historyczną o sztuczkach prawniczych i funkcjonowaniu trybunału w czasach saskich. Wyszedł z tego obraz niezwykle krytyczny, stojący w opozycji do pojawiających się dobrotliwych opisów przedrozbiorowego wymiaru sprawiedliwości. Sąd funkcjonuje źle, trudno o niesprzedajnych sędziów i uczciwych adwokatów. Choć sama powieść nie należała do najpoczytniejszych, to jednak twórczość Kraszewskiego była znana i oddziaływała na kolejnych piszących - w tym wypadku utwierdzając negatywny obraz staropolskiego sądownictwa oraz dawnej palestry.
\end{abstract}

Słowa kluczowe: Józef Ignacy Kraszewski, Maleparta, Lublin, Trybunał Koronny, palestra staropolska, powieści historyczne, prawo i literatura.

\section{Wstęp}

Dawne sądy i palestra to temat pojawiający się zarówno w literaturze przedrozbiorowej, kiedy pisano o teraźniejszości, jak i późniejszej, gdy już tylko malowano obrazy przeszłości. W obu przypadkach na kartach poszczególnych dzieł znajdziemy najczęściej tylko krytykę lub ośmieszenie różnych wad sądownictwa i ludzi, którzy je tworzyli. Niewiele za to jest utworów literackich, w których przedstawiono szczegóły funkcjonowania staropolskiego wymiaru sprawiedliwości czy świata ówczesnych prawników. Do nielicznych wyjątków należy wydana w czterech tomach Maleparta. Powieść historyczna z XVIII wieku Józefa Ignacego Kraszewskiego. To jedna z pierwszych powieści historycznych autora nazywanego ojcem tegoż gatunku w naszej literaturze. W imponująco bogatym dorobku pisarza (tak 
obszernym i różnorodnym, że stanowi on poważny problem dla wszystkich badaczy $\left.^{1}\right)$ Maleparta ze względu na poruszoną tematykę jest utworem szczególnym. Choć Kraszewski w kolejnych powieściach kreślił nieraz jeszcze sylwetki osób związanych z sądownictwem, poruszał tematykę sądową czy nawet trybunalską (m.in. Historia o Janaszu Korczaku i o piękniej miecznikównie, Syn marnotrawny, Saskie ostatki, a na kartach Grzechów hetmańskich odnajdziemy nawet postać obmierzłego jurysty Kunasewicza), to nigdy więcej już nie uczynił mecenasa głównym bohaterem większego dzieła.

Trzeba jednak od razu zauważyć, że sama powieść odniosła raczej umiarkowany sukces, choć przyczyn tego nie należy szukać w jej prawniczej tematyce. Po raz pierwszy wydana została w czterech tomach w Lipsku w $1844 \mathrm{r}$. W przeciwieństwie do wielu innych utworów Kraszewskiego doczekała się zaledwie dwóch kolejnych wydań, wszystkie ukazały się jeszcze w XIX w. ${ }^{2}$ Już po ukazaniu się pierwodruku krytycy wskazywali na liczne niedostatki powieści, określając ją mianem „miernej”. Nie szczędzono zarzutów - źle zarysowane postaci, nieprawdopodobne wydarzenia i niewiarygodna fabuła czy wreszcie zakończenie, czyli „ustęp niewcze-

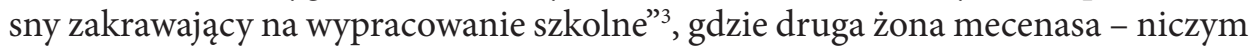
słynna Rozalia z Chodkiewiczów Lubomirska - ginie na szafocie w rewolucyjnym Paryżu. Późniejsi badacze również nie cenili tego dzieła, rzadko przeprowadzając jakiekolwiek analizy jego treści i wspominając je w najlepszym razie jako nieudane ${ }^{4}$. Gdy jednak przedmiotem zainteresowania uczynić nie literackie czy artystyczne wartości, a to, jak ukazane zostało sądownictwo trybunalskie i jego adwokatura, wówczas powieść Kraszewskiego dostarcza sporo interesującego

1 Trudne jest nawet zliczenie i zestawienie całego dorobku, zob. T. Budrewicz, Biografie Kraszewskiego i ich potencjat legendotwórczy, [w:] tegoż, O Kraszewskim. Studia, Kraków 2013, s. 21-26.

2 Wydanie pierwsze z 1844 r. w Lipsku przez Jana Nepomucena Bobrowicza, w Księgarni Zagranicznej; wydanie drugie z 1862 r. w Brukseli przez Zygmunta Gerstmanna jest właściwie wydaniem pierwszym - Gerstmann po bankructwie Bobrowicza przejął zalegające u niego nakłady i dorabiał do istniejących tytułów nowe okładki, zob. H. Batorowska, Jan Nepomucen Bobrowicz: polski wydawca i księgarz w Saksonii w czasach Wielkiej Emigracji, Kraków 1992, s. 144; wreszcie wydanie trzecie (de facto - drugie) wyszło w 1874 r. we Lwowie u Gubrynowicza i Schmidta, a w Warszawie u Michała Glücksberga, w ramach wielotomowego zbioru powieści Kraszewskiego. Wszystkie zamieszczone tu cytaty i wskazania stron odnoszą się do tego wydania (tom, strona), poprawionego przez autora.

3 Kronika literacka, „Biblioteka Warszawska” 1844, t. 4, s. 210-218; O kilku dziełach z lekkiego piśmiennictwa w ostatnich czasach, „Przegląd Poznański” 1845, t. I, s. 56-63.

4 Wincenty Danek, znawca twórczości Kraszewskiego, określit ją jako dużą, nieudaną powieść, zob. W. Danek, Kraszewski i Walter Scott, „Rocznik Naukowo-Dydaktyczny WSP w Krakowie. Prace historyczno-literackie” 1963, z. 17, s. 8; w późniejszej monografii zaliczył Malepartę do powieści Kraszewskiego, które przyniosły słabe rezultaty artystyczne, zob. tenże, Powieści historyczne J. I. Kraszewskiego, Warszawa 1966, s. 91. Wreszcie w biografii Kraszewskiego pisał, że Maleparta to eksperyment, „dziwaczna i rozwlekła opowieść”, zob. tenże, Józef Ignacy Kraszewski, Warszawa 1973, s. 230-232. 
materiału. Metryka wskazuje, że pisarz nie mógł sam poznać staropolskiego wymiaru sprawiedliwości, a to, co pisał, opierać się musiało na jego znajomości historii i źródeł. Jest to więc świadectwo początków kształtowania się obrazu przedrozbiorowego sądownictwa i adwokatury - obrazu tworzonego przez ludzi i dla ludzi, którzy nigdy nie widzieli go w działaniu. I choć Kraszewski jako autor nie jest dziś ani poczytny, ani doceniany, to jednak inaczej było za jego życia - twórczość ta wywierała przemożny wpływ na innych pisarzy i na „mentalność publiczności czytającej”" Oczywiście zakres tego wpływu trudno oszacować, nie znając ani nakładów, ani wziętości i szczegółów rozchodzenia się książki w społeczeństwie ${ }^{6}$, tym bardziej, że chodzi o dzieło znacznie mniej popularne (biorąc pod uwagę choćby liczbę wydań) od wielu innych powieści Kraszewskiego. Józef Korzeniowski, dziś nieco zapomniany, ale w połowie XIX w. znany dramaturg i poczytny powieściopisarz, pomimo pewnych zastrzeżeń po lekturze Maleparty pisał, iż to „rzecz dobrze przemyślana i poprowadzona"7. Współczesny regionalista Zbigniew Włodzimierz Fronczek podaje, że „[p]owieść zrobiła furorę”, a zainteresowanie jej bohaterem do dziś nie słabnie ${ }^{8}$.

Niniejsze rozważania stanowić mogą punkt wyjścia dla dalszych badań zarówno nad literackim przedstawieniem dawnego sądownictwa i adwokatury, jak i jego odbiciem w świadomości historycznej społeczeństwa. Wstępnie można założyć, że obraz odmalowany na kartach powieści mógł kształtować późniejsze wyobrażenia o staropolskiej palestrze i wymiarze sprawiedliwości.

\section{Akcja powieści}

Głównym bohaterem powieści jest tytułowy adwokat - Jan Aleksander Paprocki nazywany Malepartą. Wytłumaczono to w następujący sposób: „Maleparta, bo wszystko, co ma, czem pobogaciał, nie poczciwej to pracy owoc, ale maleparta, zły nabytek. A zły nabytek, nie idzie w pożytek [...] maleparta, do czarta” (I, 26).

5 J. Bachórz, Józef Ignacy Kraszewski, [w:] Literatura krajowa w okresie romantyzmu 1831-1863, t. III, red. M. Janion, M. Maciejewski, M. Gumkowski, Warszawa 1992, s. 440. Zob. też: W. Danek, Józeflgnacy..., s. 436-440.

6 Por. J. Maternicki, Kultura i edukacja historyczna społeczeństwa polskiego w XIX w. Zarys problematyki i postulaty badawcze, [w:] Edukacja historyczna społeczeństwa polskiego w XIX w. Zbiór studiów, red. J. Maternicki, Warszawa 1981, s. 106-109.

7 Korespondencja Józefa Ignacego Kraszewskiego. Seria III: Listy z lat 1844-1862, t. 9, k. 504 (BJ rkps $6468 \mathrm{IV})$.

8 Z.W. Fronczek, Lubelska historia nikczemności. Encyklopedia legend, sensacji i anegdot Lublina, Lublin 2009, s. 103. 
Akcja powieści w przypadku dwóch pierwszych tomów toczy się w trybunalskim Lublinie, gdzie poznajemy głównego bohatera praktykującego w zawodzie. $\mathrm{W}$ treść tomu pierwszego wplecione jest też (mające charakter gawędy) retrospektywne opowiadanie, dzięki któremu dowiadujemy się o wcześniejszych losach bohatera. Przygarnięty sierota zostaje mecenasem i dorabia się ogromnego majątku. Jego życie prywatne stanowi jednak pasmo oszustw i najgorszych zbrodni - licząc na duży majątek, żeni się z Rózią Mrozicką. Doprowadza najpierw do śmierci swej teściowej, potem więziona przez niego żona ucieka i skrywa się w klasztorze. Pomocy udziela jej deputat Stanisław Górski. Z zemsty Maleparta śmiertelnie go rani, wcześniej jeszcze omyłkowo zabija jego towarzysza. Prawnik wreszcie porywa ukrywającą się żonę, a następnie ją również doprowadza do śmierci. Jako mecenas przyjmuje najbardziej odrażające i niesprawiedliwe sprawy - sprawy nie do wygrania, które on jednak wygrywać potrafi. W swej praktyce stosuje oczywiście oszustwa i najpodlejsze wybiegi. Daje mu to finansowe powodzenie, choć $\mathrm{w}$ jego sytuacji istotne jest przede wszystkim odzyskanie i zagarnięcie ogromnego majątku żony, a także wyprocesowanie dla siebie magnackiej fortuny zabitego deputata Górskiego. Nienasycony bogactw, cały czas pomnaża majątek, „, [ż]ycie jego było ciągłą walką i ciągłem, uzuchwalającem go do nowej, zwycięztwem; nic mu się oprzeć nie mogło, broił bezkarnie, naśmiewał się z poczciwych, i im dłużej to trwało, tem śmielszy brnął dalej, a dalej” (II, 95).

Dwa ostatnie tomy - choć opowiadają dalsze losy Maleparty - nie przynoszą już obrazu ani palestry, ani praktyki adwokackiej. W tomie trzecim wzbogacony lubelski mecenas przenosi się na wieś, gdzie rozpoczyna się jego błyskotliwa kariera jako ziemianina i szlacheckiego polityka. Tom czwarty to kolejne przenosiny Maleparty - już posła - tym razem do Warszawy, jego upadek, pokuta i śmierć. Widzimy, jak parweniusz i dorobkiewicz sięga zaszczytów, a potem traci wszystko. Przeszłość lubelska jest już wówczas tylko czymś, co mu ciąży i od czego próbuje się odciąć, ale to też ona go ostatecznie pogrąża. Zresztą dwa pierwsze tomy łatwo przeciwstawić dwóm ostatnim, w których przygody bohatera stają się coraz mniej realistyczne i ciekawe, a całości ciąży dydaktyzm, moralizatorstwo i polityczne poglądy autora. Określenie Maleparty jako polemiki z pochwalnym obrazem sarmackiego życia ukazanym w niezwykle popularnych gawędach Henryka Rzewuskiego ${ }^{9}$ jaskrawo więc odnosi się przede wszystkim do dwóch pierwszych tomów. Ba, nie tylko samo przysłowie o Maleparcie znajdziemy na stronach Pamiątek Soplicy, ale też pojawia się tam choćby krótki opis rzeczywistości trybunału lubelskiego ${ }^{10}$. Świat przedstawiony przez Rzewuskiego zawiera wiele podobnych motywów, jednak są one ukazane w innym świetle - mamy barwne życie trybunalskie, ale pojedynek na szable kończy się

9 J. Jarowiecki, Powieści historyczne Ignacego Kraszewskiego (geneza i klasyfikacja), „Rocznik Naukowo-Dydaktyczny Studium Terenowego Krakowskiej WSP w Tarnowie. Nauki humanistyczne" 1961, z. 1; W. Danek, Kraszewski i Walter..., s. 8.

10 H. Rzewuski, Pamiątki Soplicy, opr. Z. Szweykowski, Wrocław-Warszawa 2004, s. 99-125, 329. 
zgodą, z kolei wdowa niesprawiedliwie wyzuta z majątku odzyskuje go. W powieści Kraszewskiego okres praktyki lubelskiej Maleparty jest wypełniony różnymi zdrożnościami, ale jawi się jako przemyślany i zręczny, krytyczny i po prostu alternatywny wobec Pamiątek Soplicy obraz staropolskiego sądownictwa i trybunalskiej palestry. I jak w każdej powieści historycznej, skłania do pytań o stosunek rzeczywistości historycznej do świata przedstawionego przez pisarza.

\section{Czas akcji}

Powieść osadzona jest w realiach XVIII w., choć czas akcji nie został precyzyjnie określony. Należałoby jednak zastanowić się nad klasyfikowaniem Maleparty - jak zwykło się robić - jako pierwszej powieści Kraszewskiego o czasach stanisławowskich $^{11}$. Niewątpliwie - co wynika z treści - w tej epoce umiejscowiona jest akcja ostatniego tomu, jednak okres lubelski pasuje opisem realiów do epoki saskiej ${ }^{12}$. Stąd należałoby uznać, że powieść łączy dwie epoki - akcja rozpoczyna się w czasach saskich, a kończy w stanisławowskich. Można znaleźć szereg argumentów (mniej lub bardziej ważkich) za tym, by tę część akcji, która toczy się w Lublinie, umieścić właśnie w epoce saskiej.

Jaskrawe zdrożności trybunalskie były przecież domeną czasów sprzed wstąpienia na tron Stanisława Augusta, bo po 1764 r. wiele z nich udało się wyeliminować. Co więcej, pierwsze reformy czasów stanisławowskich mocno ograniczyły czas i zredukowały znaczenie kadencji lubelskiej oraz towarzyszący jej przepych - choćby ze względu na to, że przypadać ona musiała częściowo w czasie Wielkiego Postu ${ }^{13}$. Kraszewski natomiast od samego początku rysuje barwny obraz hałaśliwego trybunalskiego Lublina - nawet jeśli robi to, przeciwstawiając go dzisiejszemu, tj. współczesnemu autorowi miastu połowy XIX w. (I, 7-8).

11 Tak zakwalifikowano ją już za życia Kraszewskiego, zob. W. Smoleński, Czasy Stanisława Augusta w powieściach J. I. Kraszewskiego, [w:] Ksiq̨żka jubileuszowa dla uczczenia pięćdziesięcioletniej działalności literackiej J. I. Kraszewskiego, Warszawa 1880, s. 215-249. Później trzymano się tej opinii, zob. np. P. Chmielowski, Józef Ignacy Kraszewski. Zarys historyczno-literacki, Kraków 1888, s. 168; J. Jarowiecki, Powieści historyczne Ignacego Kraszewskiego..., s. 164; W. Danek, Powieści historyczne..., s. 29.

12 Niekonsekwentnie podszedł do tego Aleksander Bar, zauważywszy najpierw, że Kraszewski podziwiał opis trybunału epoki saskiej dokonany przez Krasickiego i sam z niego skorzystat w Maleparcie, po czym stwierdził jednak, że w tej powieści pisarz to właśnie „[w]iek Stanisława Augusta odmalował w najczarniejszych barwach” - A. Bar, Charakterystyka i źródta powieści Kraszewskiego w latach 1830-1850, Warszawa [ok. 1923], s. 10-11, 77.

13 Zob. K. Gombin, Trybunat Koronny. Ceremoniat i sztuka, Lublin 2013, s. 53. 
To oczywiście nie może być argumentem rozstrzygającym. Istotniejszy jest fakt, że zmieszczenie toczącej się w Lublinie akcji w czasach stanisławowskich po prostu nie jest możliwe. Gdy Maleparta jako poseł ląduje wreszcie w stolicy, Kraszewski dość precyzyjnie określa, że „[w] esoło było w Warszawie pierwszych lat panowania Stanisława Augusta" (IV, 13). By było to możliwe, wcześniejsza akcja musiała się toczyć w epoce saskiej. Licząc skromnie, na wszystkie powieściowe wydarzenia lubelskie potrzeba by najmniej siedmiu-ośmiu lat, a do tego doliczyć należy też czas, który mecenas spędził na wsi, ożeniwszy się tam i przyjąwszy funkcję posła. Trybunalskie kadencje odbywały się corocznie, więc gdy dowiadujemy się, że deputat Stanisław Górski „[n]a następny trybunał już nie przybył”, a pojawił się ponownie, to musiały minąć co najmniej dwa lata, zwłaszcza że uwięziona żona Maleparty spędzała „[c]ałe dnie, całe lata sama z sobą w izdebce” (I, 106-107). Po pojedynku z deputatem Górskim Maleparta wygrywa proces o jego majątek na rzecz starosty Wilskiego. Następnie uzyskuje pieniądze od Wilskiego, reprezentując krewnych zmarłego deputata, których potem również pozbawia kapitału (II, 93-94) - na co konieczne są najmniej trzy lata i trzy kadencje trybunalskie. Natomiast po porwaniu i ponownym uwięzieniu żony znów mamy informację, że „[u]pływały dnie, tygodnie, miesiące” (II, 99). Potem wreszcie mamy romans mecenasa z Naścią, śmierć żony i żałobę, po której zakończeniu kochanka oczekuje, że prawnik się z nią ożeni. Zachodzi bowiem w ciążę, dziecko jednak umiera, a romans kończy się „[w] następnym wszakże roku” (II, 111). Ciągu tych zdarzeń nie da się wcisnąć $\mathrm{w}$ nawet najszerzej ujmowany początek czasów stanisławowskich, tym bardziej, że w pierwszych latach panowania ostatniego króla odbyły się tylko cztery kadencje (1765-1768), później Trybunał wznowił pracę dopiero w $1773 \mathrm{r}$. Wtedy też po kilkuletniej przerwie wybrano posłów na sejm, wcześniej bowiem zbierał się on w 1764, 1766 oraz pracował na przełomie 1767 i $1768 \mathrm{r}$.

W tym kontekście wreszcie rozstrzygające powinno być to, że nieskuteczność swoich zabiegów po przyjeździe do Warszawy starosta Poraj tłumaczy nowymi stosunkami - śmiercią Augusta III i zmianą dworu (IV, 17). Oznacza to, że Maleparta trafił do stolicy na samym początku panowania ostatniego króla i dopiero akcja ostatniego tomu powieści toczy się w czasach stanisławowskich.

Tezę tę trzeba oczywiście rozpatrywać w kontekście typowego dla Kraszewskiego pospiesznego i niedbałego stylu. Chronologia nie jest mocną stroną powieści, trudno ustalić ją z całą pewnością, ponieważ z łatwością można w niej dostrzec różne niekonsekwencje. Za przykład niech posłuży Zuzia, która ma lat dwadzieścia kilka, gdy wychodzi za Malepartę (III, 18) i rodzi w Warszawie dziecko (IV, 44-46). Jest to właśnie Warszawa początków epoki stanisławowskiej, ale urodzony wówczas Albert jest wciąż jeszcze dziecięciem, kiedy to jego matka zostaje podczas rewolucji francuskiej ścięta na gilotynie (IV, 91). 


\section{Palestra}

Środowisko prawników przedstawione na kartach powieści jest liczne: mamy prezydenta, deputatów i korowód mecenasów, plenipotentów oraz stron procesowych. Palestra pojawia się na początku, okupując schody trybunalskie (I, 8). Zresztą prawnicy portretowani są przede wszystkim jako zbiorowość, przy czym niekonsekwentne użycie terminu „palestra” odnosi się raz do mecenasów, innym razem do palestrantów i praktykantów adwokackich. Poza głównym bohaterem szczegółowo opisanych zostało tylko trzech mecenasów - Przepiórkowski, u którego młody Maleparta praktykował, Zawada, który reprezentował żonę głównego bohatera, oraz Prozorowicz, który opowiadając dzieje Maleparty, występuje już jako eksmecenas.

Paprockiego jako ubogiego sierotę przygarnął i wychował mecenas Przepiórkowski, który „komu mógł, dopomagał, a nikomu nie zaszkodził nigdy” (I, 41). Przy nim główny bohater został aplikantem i wyuczył się zawodu tak, że gdy pierwszy raz zastępował swego pryncypała, po rozprawie Prozorowicz rzekł, „że z niego będzie człowiek i prawnik zawołany" (I, 44).

Dobroduszny starszy mecenas Zawada - uczciwy i religijny - „był jednym z tych ludzi prawych, o których prawości nikt nawet nie wątpi” (II, 12). On to podjął się reprezentować Rózię Mrozicką, czyli żonę Maleparty przez niego dręczoną. Stało się to po jej ucieczce i ukryciu się w klasztorze.

Wreszcie Prozorowicz, który zasiadał przy stoliku pod schodami trybunalskimi, aby jako skryba pisać chętnym dokumenty procesowe. Był to człowiek, który co „napisze, to przepije, i wytrzeźwiony pisze znowu, i napisawszy, znowu pije”. Ów dawniej „wzięty prawnik” stoczył się za sprawą młodej żony (później - jak niedwuznacznie zaznaczono - zmarłej w Warszawie in hospicio) i swego pijaństwa, choć wciąż go szanowano (I, 10-11). Jak stereotypowy mecenas używając języka prawnego, wrzuca terminy łacińskie (I, 11, 14), a nawet zwykłą łacinę (I, 25, 27, 33, 36). Z wyrzutem mówi, że „gdyby się to miało cokolwiek mniej skrupułów, szersze sumienie; dalej by się zaszło! Na tym świecie, tylko łotrom płuży, a poczciwym żal się Boże!” (I, 27). W innym miejscu, niejako oskarżając tym samym pozostałych mecenasów, wspomina, że sam "nigdy z drugiemi na wybiegi nie chodził i nie zwyciężał przeciwników pędzeniem rejestru, nadrabianiem kondemnat" (I, 42).

Mimo obecnej kondycji Prozorowicza każdego z trzech przedstawionych mecenasów należy uznać za postaci pozytywne. Wyróżniają się oni wśród lubelskiej palestry, wspominanej tylko incydentalnie i potraktowanej zresztą już tylko jako zbiorowość. Wprawdzie nie wszyscy współpracują z Paprockim, ale z niecną sprawą sukcesyjną Czerniawskiego prowadzi do Maleparty dwóch lubelskich prawników, w tym niejaki Pęchalski (II, 40). Podobnie pojawia się „dwóch z palestry trybunalskiej z księgami i papierami”, gdy dochodzi do zawarcia umów z Mrozickimi, matką i córką, kiedy to „kobiety, znużone i struchlałe, nie miały czasu namyślić się, cofnąć, zaprzeczyć” 
(I, 89). Prócz tego palestra występuje tylko w kontekście pijaństw i burd („Powadziło się dwóch palestrantów z jakąś szlachtą i już mieli się do szabel”, I, 20).

Mamy też ubogich mecenasów „bez spraw et per consequens bez chleba”, którzy wysługiwali się znaczącym patronom, a gdy im się trafiała własna sprawa, gmatwali ją, rozdmuchiwali i ciągnęli latami. Gdy zamiast do któregoś ze „sławnych i wziętych mecenasów lubelskich" przyjezdny szlachcic trafiał do takiego kauzyperdy, ten, samemu się wzbogacając, doprowadzał swego klienta do ruiny (I, 11-12). Tego typu prawnicy stali również za upadkiem wdowy Heleny Mrozickiej („wpadłszy w ręce takich prawników, co z niej ciągnęli, póki mogli, przedając ją adwersarzom, zubożała z kretesem", I, 52).

Wreszcie bohater tytułowy. Sam Maleparta był niewątpliwie świetnym prawnikiem - wszak „[n]ie obeszła się konferencja żadna bez niego, a nieraz z konfuzją starszych pokazał jasną drogę, gdzie oni nie widzieli nic prócz ciemności” (I, 47). Sam zaś „nie radził się nikogo, prócz siebie” (I, 73). Brał sprawy „niepodobne do wygrania dla braku dowodów lub przemocy strony przeciwnej. Te procesa wiódł on nie dla czego innego, tylko dla podwyższenia jeszcze renomy swojej" (I, 46). Potrafił wykorzystać niedostatki dawnego prawa, jak sam tłumaczył: „prawa nasze w rzeczach sukcesji wielce są niedostateczne i ciemne, żywić się muszę wykładem i prejudykatami" (II, 42). Niejako w kontraście do niego naszkicowana jest postać wspomagającego go niezbyt błyskotliwego dependenta, który jednak na zawołanie wypełniał wszelkie zlecenia mecenasa.

O ile jednak fachowości nie sposób Paprockiemu odmówić, o tyle od samego początku swej kariery adwokackiej dał się jako człowiek poznać z jak najgorszej strony, ponieważ po śmierci swego preceptora poszedł od razu na swoje, biorąc reprezentację krewniaków w procesach przeciw wdowie. Ta skończyła na bruku, bo Maleparta „znał doskonale słabą stronę sprawy sierocej, znał papiery” i wygrał, stając się odtąd „patronem spraw diabelskich”, jak to określił Prozorowicz (I, 45-46). Podobne zdanie o nim miał deputat Górski, stwierdził bowiem, że „gdyby mu szatan od sprawy zapłacił, stanąłby w sprawie szatana; zwykle podejmuje się tylko procesów przez złego ducha natchnionych" (I, 81).

Prozorowicz tak charakteryzował jego praktykę:

najgorsze, najniepewniejsze, najohydniejsze sprawy przyjmował. Kiedy się nikt z palestry podjąć procesu nie chciał, wyprawiano stronę do Paprockiego, a on odarłszy sowito, brał go z najzimniejszą krwią do prowadzenia. Nabijał trzos szybko, bo sumienia swojego zaparł się zupełnie. A przez to szperanie, ślęczenie, sztukowanie, jak by ze złej sprawy zrobić dobrą, jak by czarne pokazać białem, nabył przy swoim naturalnym dowcipie takiej znajomości prawa, prawności, form, że starzy, co zęby zjedli u trybunału, nieraz mu się dziwowali. A choć wszystko, co było poczciwego, stroniło od niego, jednak każdy aktor, gdy przyszło do konferencji, wyprosił u nas, żeśmy go powołać na nią musieli (I, 46).

Jego postępowanie było powszechnie znane, więc przynajmniej część palestry i zwykli ludzie brzydzili się z nim obcować. Jednak skutecznie zdobywał majątek: 
Nabycia majętności nie dopełniał też ten człowiek zwyczajnym sposobem, uczciwie. Zwykle kupował od zrujnowanych lub przyjmował na siebie obarczone procesami i długami substancje za nizką cenę; potem ze zręcznością jurysty wyprowadzał się z procesów, spychał, unieważniając długi, wchodził z kredytorami w korzystne układy, i tak opanowywał dobra ogromne (II, 93).

Dopiero gdy zrealizował swój cel i zdobył wielką fortunę, zyskał dzięki jej posiadaniu pewien szacunek (II, 96).

\section{Deputaci i inne osoby związane z sądownictwem}

Deputaci trybunalscy, tak jak ociężały i gnuśny marszałek, również nie prezentowali się dobrze. Drugi deputat oddawał się swawolom, ale namiętnościom „nie dał się jeszcze zawojować”. Dopiero trzeci był nieprzekupny i uczciwy, więc żył skromnie i z dala od wszelkiego towarzystwa - „[j]ak zapowietrzony”. Kraszewski rysuje go w pewnym sensie jako jedynego sprawiedliwego, który sam radził się uczciwego i biegłego prawnika, a „swym współtowarzyszom piekącą wymówkę przedajności lub lekkości w oczy” potrafił rzucić i „[p]atrzał z litością na jednych, z pogardą na drugich” (I, 16-18). Ponieważ ów Zieliński był wyjątkiem, wystarczyło go zneutralizować, by uzyskać odpowiedni wyrok z pomocą skorumpowanej reszty deputatów (II, 79).

Sprzedajność sędziowska jest mocno podkreślana przez Kraszewskiego. Gdy było trzeba, zainteresowany wygraną „odwiedził starosta wskazanych mu deputatów, których listę mu dano” (II, 42). Później znów udał się

w odwiedziny do jegomościów panów deputatów, [Maleparta] doradził mu najlepiej, którego czem miał ująć, jak się któremu przypochlebić, przestrzegł, do kogo napróżno by się trudził. Posłuszny litygant puścił się do wrót, z ukłonami i zaprosinami, otwarł dom, nakrył stół, kupił wina i częstował, kłaniając się jak najniżej, upatrując tylko, na czem spoczęło oko którego deputata, aby mu zaraz ofiarować; to rzędzik sadzony, to bogato oprawną karabelę, to konia, to zegarek, to strzelbę (II, 78).

Szerzej opisany pośród deputatów jest Stanisław Górski, ofiara Maleparty. Wprawdzie posiadał liczny dwór i prowadził hulaszczy tryb życia, wyprawiając uczty (choć sam wina nie pijał) i polowania, ale był uczciwy i wszystkim pomocny. Jako człowiek majętny wspomagał potrzebujących. „Życie pana Stanisława było mieszaniną zabaw, hulanki, dobrych i świętych uczynków, szału, swawoli i dobroczynności” (I, 107-108; II, 25-28).

$\mathrm{Na}$ ulicach miasta mamy gwardię trybunalską, a z urzędników trybunalskich, poza woźnym i instygatorem, wspomniany jest jedynie regent trybunalski, którego szuka deputat Górski (I, 81). 
Prócz tego mamy do czynienia z mnóstwem bohaterów w ten czy inny sposób związanych $\mathrm{z}$ toczącym się w Lublinie sądownictwem trybunalskim. Nieodzownym jego elementem jest Czubak, zawodowy fałszerz dokumentów, z którego usług korzysta Maleparta (II, 45-50; II, 106). Jest też kręcąca się amorficzna „hałastra”, gromada podejrzanych ludzi („cygańskie świadki”, jak określa ich Prozorowicz), których można było wynająć, jako że dla pieniędzy gotowi byli do dania w sądzie „fałszywego świadectwa, fałszywej przysięgi lub po prostu szabli do najazdu, siły do zemsty" (I, 12-14).

Kolorytu sądownictwu dodaje szereg dalszych postaci. Wspomniani są żebracy przybywający na reasumpcję trybunału (II, 32), a obrazu zepsucia dopełniają kobiety, „co na trybunał jak na bal zjeżdżały, wabiąc do swych domów nieostrożną bogatą młodzież” (I, 15). Sam Maleparta też rzuca swej kochance: „przede mną kochałaś kilku już palestrantów" (II, 110).

\section{Literacka fikcja a prawda historyczna}

Jak podkreślają badacze, Kraszewski uważający się za historyka nie potrafił się uwolnić od historii w swojej twórczości, wplatał więc w swe dzieła materiały źródłowe czy beletryzował autentyczne zdarzenia ${ }^{14}$. Zwłaszcza w pierwszych swych powieściach historycznych trzymał się faktów, fabularyzując źródła ${ }^{15}$. Władysław Smoleński oceniając jednak powieść, stwierdził, że poza procedurą sądową cała reszta nie pasuje do epoki i jest tylko fantazją autora, co wynika z deficytu źródeł w chwili, gdy Kraszewski ją pisał ${ }^{16}$. Mimo to w przypadku Maleparty badacze ochoczo wspominają, że pierwowzorem bohatera powieści był prawdziwy adwokat, o losach którego usłyszeć miał Kraszewski podczas swego pobytu w Lublinie. Sam autor wspomina o tym we wstępie do wydania powieści z 1874 r., co nie może być jednak przekonującym argumentem, modna wówczas była bowiem konwencja autorska sugerująca czytelnikom, że dzieło zostało oparte na prawdziwych historiach czy odnalezionych rękopisach.

Niestety, do tej pory nie udało się ustalić nic więcej, a badacze poprzestają na wspomnieniu, że dzieje mecenasa oparte są na autentycznej zasłyszanej historii ${ }^{17}$.

14 W. Danek, Kraszewski i Walter..., s. 14; J. Bachórz, Józef Ignacy..., s. 488; J. Jarowiecki, Źródła powieści historycznych Józefa Ignacego Kraszewskiego o czasach stanisławowskich, „Rocznik Naukowo-Dydaktyczny WSP w Krakowie. Prace historyczno-literackie" 1963, z. 17, s. 61.

15 W. Danek, Józef Ignacy..., s. 226-227.

16 W. Smoleński, Czasy Stanisława Augusta..., s. 242.

17 Tak np. J. Bachórz, Józef Ignacy..., s. 488. 
Jedynie Wiktor Hahn, uznając Malepartę za postać autentyczną ${ }^{18}$, starał się to udowodnić, powołując się na recenzję $\mathrm{z}$ epoki. Jest to o tyle ciekawe, że w tym samym czasie złośliwy recenzent „Przeglądu Poznańskiego” zauważył, że nikt w Lublinie o głównym bohaterze powieści nie pamięta ${ }^{19}$. Dzisiejszy regionalista wspomina o żywej legendzie jedynie w odniesieniu do zakończenia życia pokutującego widma eksmecenasa ${ }^{20}$. Drugim źródłem, które zdaniem Hahna potwierdzało istnienie Paprockiego, były teksty Antoniego Andrzejowskiego, które ukazały się jednak kilkanaście lat po wydaniu Maleparty. Trudno więc zawyrokować, czy ich autor pisał o własnych doświadczeniach, czy zaadaptował do nich postać ze znanej sobie powieści. Późniejszy wydawca trafnie zauważył, że poza własnymi przeżyciami Andrzejowski wplótł do swych wspomnień opowiadania innych, które „pozbawione charakteru materiału historycznego” są tylko „mieszaniną fantazji i rzeczywistości” ${ }^{21}$. Informacja ta jest tym bardziej niewiarygodna, gdyż Maleparta miał jakoby brać udział w „rozwodzie” Fryderyka Moszyńskiego z Teofilą Potocką, który odbył się w 1764 r. $^{22}$, a w tym czasie bohater powieści (jak wyżej wykazano) od dawna już zaniechał praktyki i żył na wsi. Podobne znaczenie musi niestety mieć spisana później legenda, która wydaje się w całości oparta na powieści Kraszewskiego. Tak samo więc niegodziwy mecenas jest tam prawnikiem praktykującym w czasach stanisławowskich ${ }^{23}$.

W takiej sytuacji, nawet jeśli Maleparta był postacią historyczną, to prawdopodobnie żyć musiał pod innym nazwiskiem niż Paprocki. Wprawdzie pojawia się ono w ówczesnym Lublinie (np. Jan Paprocki, egzaktor i pisarz tabaczny ${ }^{24}$ ), ale w dostępnych źródłach brak wzmianek o nazywającym się tak mecenasie. Dalsze

18 W. Hahn, Lublin w twórczości Józefa Ignacego Kraszewskiego, Lublin 1925, s. 19-21.

19 O kilku dziełach..., s. 57.

20 Z.W. Fronczek, Lubelska historia..., s. 104.

21 F. Rawita Gawroński, Kilka słów o Autorze i jego pamiętnikach, [w:] A. Andrzejowski, Ramoty starego Detiuka o Wotyniu, t. I, Wilno 1921, s. 13.

22 K. Wierzbicka-Michalska, Moszyński August Fryderyk, [w:] „PSB”, t. 22, Wrocław-WarszawaKraków-Gdańsk 1977, s. 108-112; A. Andrzejowski, Ramoty..., s. 172-175.

23 W.J. Śliwina, Podanie o Maleparcie, [w:] Podania i legendy Lublina, opr. A. Wójcikowski, W. Wójcikowski, Lublin 2001, s. 80-82. Podaną przez autorkę informację o tym, że o Maleparcie pisał również niejaki Wilczyński, wydawcy sprostowali, podając, że chodzi o Augusta Wilkońskiego i jego Ramoty i ramotki literackie. Nie udało się jednak takiej opowieści o mecenasie odszukać, pomimo przejrzenia różnych wydań tego dzieła. Zapewne za tym źródłem powtórzył to J. Malik, Miasto dwóch miast. Wokót powieści Józefa Ignacego Kraszewskiego „Maleparta”. Dopowiedzenia, [w:] Europejskość i rodzimość. Horyzonty twórczości Józefa Ignacego Kraszewskiego, red. W. Ratajczak, T. Sobieraj, Poznań 2006, s. 110, przyp. 20. Z drugiej strony można znaleźć późniejszą zagadkową, odmienną edycję legendy o Maleparcie, w której podane są nieznane szczegóły życia Maleparty, zob. http://www.biblioteka.teatrnn.pl/ dlibra/dlibra/docmetadata?id=9237\&from=publication (dostęp: 1.07.2020).

24 J. Kermisz, Lublin i lubelskie w ostatnich latach Rzeczypospolitej, t. 1: W czasie Sejmu Wielkiego i wojny polsko-rosyjskiej 1792 r. oraz pod rządami targowicko-grodzieńskimi, Lublin 1939, w różn. miejscach. 
jego losy, zwłaszcza epizod warszawski, również przemawiają za fikcyjnością postaci. Wprawdzie niebywała kariera dorobkiewicza, rozpoczynająca się od wejścia do grona lubelskiej palestry, nie była wówczas czymś nieprawdopodobnym ${ }^{25}$, ale posłowanie na sejm i smutny upadek musiałyby pozostawić jakieś ślady - trudno uwierzyć, by o postaci tak barwnej nie można było znaleźć jakichkolwiek świadectw z epoki. Niemożliwe jest więc przesądzenie, czy pierwowzór powieściowego Paprockiego rzeczywiście istniał, czy nie - dopóki jednak nie znajdzie się jakiejkolwiek wzmianki w aktach świadczącej o praktykowaniu przez podobnego mecenasa, trzeba traktować to jako wątpliwą hipotezę.

Za fikcyjnością postaci Maleparty mogą świadczyć bohaterowie epizodyczni występujący na kartach powieści, jak choćby trybunalski marszałek, którego szczegółowo sportretował Kraszewski. Trudno bowiem dostrzec w nim jakąkolwiek rzeczywistą postać historyczną. Kitowicz opisuje wystawny tryb życia marszałka z 1750 r. Janusza Sanguszki²6, który - podobnie jak opisywał to Kraszewski - był młodym (przed czterdziestką) senatorem i potomkiem znaczącego rodu (I, 14-15). Ale złych cech charakteru nie mogła mu zaszczepić cudzoziemska matka, bo takiej nie miał. Spośród marszałków tego okresu będących przedstawicielami znamienitych rodów warunek ten spełnia tylko Józef Lubomirski (marszałek z 1742 r.), którego matką była Joanna Karolina Stärtzhausen ${ }^{27}$. Ale ten z kolei nie był senatorem. Przyjąć trzeba, że Kraszewski na podstawie posiadanej wiedzy samodzielnie ulepił postać człowieka, którego postawił na czele trybunału. O wychowaniu pańskim - delikatnym, wyjazdach zagranicznych mógł wyczytać choćby w innym miejscu wspomnianego dzieła Kitowicza ${ }^{28}$. Warto też zauważyć, że stanowi to kolejne wskazanie na czasy saskie, bo później stanowiska marszałka właściwie nie obejmowali już przedstawiciele najznamienitszych rodów.

Bezowocne też wydają się próby utożsamiania któregoś spośród setek deputatów przewijających się przez Trybunał z pierwowzorem Stanisława Górskiego. Poszukiwania takie są skazane na niepowodzenie - Kraszewski portretował nie rzeczywiste postaci historyczne, lecz tworzył pewne ich typy. Przemawiać za tym może eksmecenas Prozorowicz, który podobny jest do innej postaci stworzonej przez Kraszewskiego: starego adwokata Paliszewskiego (opowiadanie Stary palestran $^{29}$ ), choć w przypadku tamtego marny los zgotowały mu nie pijaństwo i mło-

25 Zob. W. Łoś, Ostatni podkomorzy lubelski, „Przewodnik Naukowy i Literacki” 1891, nr 6, s. 530-536.

26 J. Kitowicz, Pamiętniki, czyli Historia polska, opr. P. Matuszewska, Warszawa 1971, s. 60-65.

27 Zob. J. Gierowski, Lubomirski Jerzy Aleksander, [w:] „PSB”, t. 18, Wrocław-Warszawa-Kraków-Gdańsk 1973, s. 21-23.

28 J. Kitowicz, Pamiętniki..., s. 477.

29 Zob. J. Bachórz, Jak się dawniej „fizjologie” pisaty, czyli Mecenas (Dawny Palestrant) Józefa Ignacego Kraszewskiego, [w:] Nowela, opowiadanie, gawęda. Interpretacje małych form narracyjnych, red. K. Bartoszyński, M. Jasińska-Wojtkowska, S. Sawicki, Warszawa 1979, s. 59-72. 
da żona, a rozbiory i koniec sądownictwa staropolskiego, gdyż mecenas był „zbyt stary, by się mógł uczyć”.

Tak samo nie sposób zidentyfikować dalszych postaci, które pojawiają się na kartach powieści (np. w Lublinie nie było burmistrza Hrehorego ${ }^{30}$ ). Wydaje się więc, że jeśli ojciec naszej powieści historycznej znał wspomnianą w legendzie postać trybunalskiego mecenasa, to uczynił ją tylko pretekstem do stworzenia literackiej fikcji - fikcji, którą ubrał w znane sobie realia historyczne. Tym samym należy przenieść datę graniczną w pisarstwie Kraszewskiego, bo już w Maleparcie mamy do czynienia z rezygnacją z wypełniania utworu elementami dokumentarnymi na rzecz wątków fikcyjnych ${ }^{31}$.

\section{7. Źródta}

Choć Kraszewski miał wiele szczegółów dotyczących przeszłości zawdzięczać opowieściom ojca i sąsiadów ${ }^{32}$, to źródło można raczej pominąć, bo nic nie wskazuje, aby historie owe mogły dotyczyć trybunalskiego Lublina ${ }^{33}$. Wiele dla ustalenia wzorów, źródeł motywów i postaci występujących w powieści uczynił Aleksander Bar ${ }^{34}$, lecz późniejsi badacze zaczęli polemizować z jego twierdzeniami ${ }^{35}$. Nie da się zaprzeczyć, że Kraszewski znał obraz staropolskiego sądownictwa z Mikołaja Doświadczyńskiego przypadków Krasickiego. Co więcej, w przeciwieństwie do wielu późniejszych badaczy $^{36}$ sam trafnie umiejscawiał lubelskie przygody Doświadczyńskiego w epoce

30 Zob. J. Riabinin, Rada miejska lubelska w XVIII w., Lublin 1933.

31 W. Danek, Józef Ignacy..., s. 461.

32 Tamże, s. 12-14.

33 W pismach Kraszewskiego znaleźć możemy niejasną wzmiankę o trudnym procesie jego prababki-wdowy w czasach saskich - sprawa „z człowiekiem możnym, królewską protekcją i deputatów trybunalskich mającego za sobą", zob. J.I. Kraszewski, Pamiętniki, opr. W. Danek, Wrocław-Warszawa 2005, s. 210-211. O zabiciu pradziadka pisał też brat pisarza (K. Kraszewski, Monografija domu Kraszewskich vel Kraszowskich Jastrzębczyków: z herbarzy, kronik, dokumentów i papierów familijnych, Poznań 1861, s. 59), ale nie napomknął nic o procesie - nie wiadomo więc, na ile tekst opublikowany w 1877 r. odbija domowe wspomnienia, a na ile wiedzę zdobytą później przez autora.

34 Poza Krasickim i Aleksandrem Fredrą wskazał nie tyle na czerpanie wiedzy, co na motywy brane od zagranicznych powieściopisarzy - Waltera Scotta, Eugeniusza Sue, Honoriusza Balzaca, zob. A. Bar, Charakterystyka i źródła..., s. 10-11, 78.

35 Chodzi np. o kwestie inspiracji Walterem Scottem, zob. W. Danek, Kraszewski i Walter...

36 Zob. P.M. Pilarczyk, Doświadczyński przed Trybunałem. Twórczość Ignacego Krasickiego w świetle historii prawa, „Pamiętnik Literacki” 2017, nr 3, s. 90-96. 
saskiej właśnie ${ }^{37}$. W dodatku opisując zdrożności trybunalskie w przypisie dotyczącym przekupstw deputatów (I, 67), jako źródło podał Satyra na twarz Rzeczypospolitej oraz odwoływał się do pamiętników Kitowicza i właśnie Mikołaja Doświadczyńskiego... Krasickiego ${ }^{38}$. Jednak to, do czego autor sam się przyznał, nie wyczerpuje wszystkich zapożyczeń. Trudno z całą pewnością ustalić korpus wykorzystanych źródeł historycznych, wszak Kraszewski był wytrwałym ich kolekcjonerem i wydawcą ${ }^{39}$, i tak jak nie wiadomo, co już mógł mieć w ręku, pisząc powieść, tak nie jest jasne, co znajdowało się w tych materiałach, do których edycji nie doszło ${ }^{40}$. Pewność można mieć tylko w stosunku do tekstów, które były już wydane. Kraszewski znał obraz staropolskiej i trybunalskiej palestry przede wszystkim z opublikowanego wcześniej dzieła Kitowicza, czyli Opisu obyczajów za panowania Augusta III $^{41}$. Wiele podobnych szczegółów dotyczących palestry znaleźć można w Stanie oświecenia w Polsce Hugona Kołłątaja, również dopiero co wydanym ${ }^{42}$. Trudno powiedzieć, czy autor posiłkował się wspomnieniami Jana Duklana Ochockiego, które - jak wskazuje biografia ich autora - właśnie wtedy powstawały i krążyły w rękopisie między wołyńskimi dworkami szlacheckimi ${ }^{43}$. Ostatecznie przecież trafiły one do Kraszewskiego, który stał się ich wydawcą ${ }^{44}$. Ochocki jednak mógł stanowić tylko punkt odniesienia, bo

37 J.I. Kraszewski, Krasicki. Życie i dzieła. Kartka z dziejów literatury XVIII wieku, Warszawa 1879, s. $129-130$.

38 Satyr... Twardowskiego, który zawiera trybunalskie scenki (S. Twardowski, Satyr na twarz Rzeczypospolitej w roku 1640, Lublin 2007, s. 30-35, w. 407-586), pochodzit jeszcze z XVII w., ale Kitowicz i Krasicki opisywali realia schyłkowej epoki saskiej.

39 Zob. A. Wierzbicki, Historiografia polska doby romantyzmu, Wrocław 1999, s. 172. Obszerny katalog księgozbioru pisarza wskazuje, że posiadał on szereg nie tylko dziewiętnastowiecznych prac, ale i przeróżnych wydawnictw z epoki (zob. M. Pawlik, Katalog księgozbioru, rękopisów, dyplomów, rycin, map, atlasów, fotografji, jakoteż osobistych dyplomów, adresów itp. pozostałych po śp. Józefie Ignacym Kraszewskim, Lwów 1888) - lecz przecież nie wiadomo, które z nich były w jego ręku, gdy pisał Malepartę.

40 Część ineditów pozostała w spuściźnie pisarza, ale wzmianki o tych, które chciał wydać, ale później zaginęły - jak pamiętniki Wojciecha Narbutta (K. Maliszewski, Bibljografja pamiętników polskich i Polski dotyczących (druki i rękopisy), Warszawa 1928, s. 372) - wskazują, że niemożliwe jest ustalenie wszystkich ewentualnych źródeł, z których Kraszewski mógł czerpać informacje. W dodatku szereg materiałów wydanych później istniało w formie rękopiśmiennej, np. stale korespondujący z Kraszewskim Michał Grabowski posiadał już w 1843 r. pamiętniki Wacława Boreyki i Karola Micowskiego (obejmujące opisy praktyki trybunalskiej), które wydane zostały dopiero w 1845 r., zob. M. Grabowski, Michała Grabowskiego listy literackie, wyd. A. Bar, Kraków 1934, s. 432.

41 Zob. J. Kitowicz, Opis obyczajów za panowania Augusta III, t. I, opr. R. Pollak, Wrocław-Warszawa 2003, s. LX-LXI.

42 Zob. H. Kołłątaj, Stan oświecenia w Polsce w ostatnich latach panowania Augusta III (1750-1764), opr. J. Hulewicz, Wrocław-Warszawa 2003, s. LXXX.

43 M. Tyrowicz, Ochocki Jan Duklan Modest, [w:] „PSB”, t. 23, Wrocław-Warszawa-KrakówGdańsk 1978, s. 496-498.

44 J.D. Ochocki, Pamiętniki Jana Duklana Ochockiego z pozostatych po nim rękopismów przepisane i wydane, opr. J.I. Kraszewski, t. 1-4, Wilno 1857. 
opisywał późniejsze czasy, gdy sądownictwo trybunalskie znajdowało się w znacznie lepszym stanie. Podobnie być mogło z również wydanymi pamiętnikami Józefa Wybickiego (1840), gdzie wystawiona została sądownictwu trybunalskiemu i palestrze jak najgorsza opinia. Przedstawiono tam wprawdzie pijaństwo i przekupstwa, ale były to realia początków panowania Stanisława Augusta i nie dotyczyły trybunału lubelskiego ${ }^{45}$. Mimo wszystkich zastrzeżeń i rzeczywistych źródeł wykorzystanych przez Kraszewskiego obraz sądownictwa trybunalskiego w Maleparcie odpowiada realiom czasów saskich.

Choć drobne obrazki oddające klimat sądownictwa trybunalskiego często są nieistotne dla akcji powieści, nietrudno dostrzec, że zostały zaczerpnięte bezpośrednio od Kitowicza. Są to zarówno elementy ceremonialne (instygator securitatis niosący krzyż i laskę marszałkowską - I, 50 ${ }^{46}$ ), jak i proceduralne („Zaczęto wołać $\mathrm{z}$ rejestru jak gradem sypał zapisując, kondemnaty po kondemnatach i pędząc. Mnie tu chodziło o to, aby utrzymać stanność i nie dopuścić, aby i nas skondemnowano. Jakoż tedy z pomocą instygatora udało się mi wykrzyknąć i sprawa przywołaną została”, I, 43). U Kitowicza też Kraszewski wyczytał oddawanie instygatorowi przez bogatych deputatów grzywien sądowych, które stanowiły ich wynagrodzenie $(\mathrm{I}, 108)^{47}$, pomysł sądzenia złapanego Maleparty z regestru directi mandati (II, 34), modlitwę po udaniu się na ustęp (II, 8, 10), spuszczanie spraw per non sunt (II, 9) czy istnienie grupy świadków do wynajęcia (I, 12-14) $)^{48}$.

Kitowicz stanowi dla Kraszewskiego pierwszorzędne źródło. Gdy karczmarz po bójce „pijaniców” ostrzega Prozorowicza i słuchającego jego opowieści palestranta o konieczności ucieczki, bo „instygator z rontem i pewnie wszystkich, co tu są, zabierze do turmy, póki indagacja o występek nie okaże, kto winien” (I,70), widać tu obrazek żywcem wzięty z Opisu obyczajów... Kitowicz pisał, że instygator securitatis musiał:

obchodzić co noc kolejno z rontem domy szynkowne, aby się w nich kłótnie i pijatyki całonocne nie działy. Jeżeli dano znać instygatorowi securitatis o wszczętej gdzie bitwie lub rąbaninie, obowiązkiem jego było co prędzej tam z rontem pospieszać i zdybanych na takowym gwałceniu publicznego bezpieczeństwa i spokojności do kordygardy zabierać. Co tylko wtenczas służyło, kiedy się bitwa toczyła między ludźmi podłymi, służalcami dworskimi albo włóczęgami, szulerstwem i rozpustą się bawiącymi, między którymi obierali się częstokroć tak sprawni do korda, że pojedynczo lub we dwóch, lub we trzech instygatorowi z rontem, z kilku i z kilkunastu żołnierzy złożonym, ciosami obdarzonym dawszy odpór, z resztą ucieczką się salwowali i zemknąwszy na czas jaki z gorącego prawa, tym samym się od chwytania uwalniali ${ }^{49}$.

45 J. Wybicki, Pamiętniki Józefa Wybickiego, senatora wojewody Królestwa Polskiego, t. 1, wyd. E. Raczyński, Poznań 1840, s. 34-39.

46 J. Kitowicz, Opis..., s. 193.

47 Tamże, s. 192.

48 Tamże, s. 216, 218, 220, 225.

49 Tamże, s. 193-194. 
Takie wykorzystanie źródeł kontrastuje z sytuacją, gdy nie ma w nich potrzebnych wiadomości - wówczas uwidacznia się brak pomysłów i ubóstwo opisów. Ponieważ dla kontynuowania gawędy Prozorowicza szynk musiał być otwarty, Kraszewski wytłumaczył ten fakt tym, że jego właściciel „okupiwszy się jakos’”, mógł to uczynić (I, 72).

Kraszewski potrafił też udanie „lepić” całe zdarzenia z różnych fragmentów zaczerpniętych z Kitowicza - przykładem jest hulanka urządzona przez deputata Górskiego (I, 108). Zdarzenie zostało ozdobione informacją o strzelaniu na wiwat przez gwardię trybunalską i o późniejszych reperkusjach w postaci napomnienia deputatów podczas kazania - Opis obyczajów... zawiera wspomnienie o takim opłacaniu strzelania podczas biesiad oraz o mszach dla deputatów, gdzie celebrujący mógł im wszystko wytknąćc ${ }^{50}$. Mamy też słynne imieniny, które wspominał Krasicki $^{51}$ - tu świętował marszałek i trzeba było odwołać sesję sądową, „bo kilku deputatów leżeli w łóżkach po pijatyce zabójczej u marszałka” (II, 17).

Mamy też pędzenie regestru, gdy wywoływane sprawy „leciały jak grad” (II, 9), tak jak u Krasickiego, gdzie sprawy też miały „spadać jak grad”"52. Trzeba zauważyć, że w przypadku szczegółów nie obyczajowych, ale praktyki procesowej i samego procesu Kraszewski pomysły podbiera już z Krasickiego, a nie Kitowicza. Widać to w działaniach samego Maleparty, który aby wygrywać sprawy, siegga po cały arsenał niegodziwych środków, będąc uosobieniem stereotypowych negatywnych cech staropolskiego adwokata. Maleparta bowiem korzysta $\mathrm{z}$ fabrykowanych dokumentów, które zamawia - jak Doświadczyński - u profesjonalnego fałszerza, potrafiącego tworzyć akta wyglądające tak, jakby pochodziły z zamierzchłej przeszłości ${ }^{53}$. To samo dotyczy szeroko przedstawionego przez Krasickiego przekupstwa deputatów ${ }^{54}$. Do sztuczek sądowych zaliczyć trzeba znaną furtkę do wznawiania zakończonych spraw, czyli de noviter repertis - po odnalezieniu nowych, nieznanych dokumentów. Tak jak u Doświadczyńskiego, tego typu dokumenty się fabrykuje, co pozwala trybunałowi na całkowitą zmianę wcześniej wydanego wyroku $^{55}$. Podobnie jak plenipotent Doświadczyńskiego Maleparta też potrafi zmieniać strony ${ }^{56}-\mathrm{w}$ jednym $\mathrm{z}$ procesów wygrywa, gdy „dokumentom przez siebie sfałszowanym zadał sam fałsz" (II, 93).

Wreszcie wspomnieć trzeba też o konferencjach adwokatów, doskonale opisanych przez Krasickiego ${ }^{57}$. Miały one znaczenie nie tylko jako forma konsultacji,

50 Tamże, s. 228, 235.

51 I. Krasicki, Mikołaja Doświadczyńskiego przypadki, wstęp B. Gubrynowicz, Wrocław-Warszawa 2005, s. 50-51.

52 Tamże, s. 59, 63.

53 Tamże, s. 60-62.

54 Tamże, s. 50-51, 63-64.

55 Tamże, s. 70.

56 Tamże, s. 80-81.

57 Tamże, s. 54-59. 
ale sztuczka procesowa. Za udział należało się mecenasom wynagrodzenie, ale jednocześnie uniemożliwiało im to późniejsze reprezentowanie strony przeciwnej. Taką niezwykle korzystną dla prawników sytuację wspomniał Kraszewski, pisząc o Paprockim, który „często-gęsto i grubo brał za konferencje i za sprawy, a nic nie tracił” (I, 46). Wspomina też, że Mrozicka „prawników na konferencje wzywała” i tam poznał ją Maleparta (I, 54). Później chciał „nabyć u nieszczęśliwej, za mało co, pretensje jej do familji i do dziedzica dóbr niegdyś dzierżawionych” (I, 55).

Paprocki jawi się jako nieodrodny syn ówczesnej palestry. Kitowicz i Kołłątaj pisali o zwadach i bijatykach prawniczej młodzieży, o walkach na kije pod trybunałem $^{58}$, które to u Kraszewskiego stały się dla Maleparty szkołą fechtunku szablą, bo ten „w pierwszych czasach swego zawodu bił się nią razy kilka” (II, 75). W innym miejscu zaś: „Nieraz przychodziło do wyzwania, do rozprawy, ale jej się nie uląkł, kat go wie, czy nosząc papiery za nieboszczykiem Przepiórkowskim i bijąc się w kije podle trybunalskiej furty, nauczył się rąbać, czy gdzieindziej, ale bił się tęgo i z taką zimną krwią, że zawsze pokiereszował, kto mu się nawinął” (I, 47).

Postać Maleparty na kartach powieści powiela i kumuluje w sobie stereotypowe złe opinie o jurystach - uważani oni byli za krętaczy, a ponieważ często ich szlacheckie pochodzenie było wątpliwe, pojawiały się pomysły pozbawienia ich możliwości posłowania na sejmy ${ }^{59}$. Pochodzenie Paprockiego również nie jest pewne, bo sam tylko określał się mianem „szlachcica”, aż wreszcie trafiła mu się sprawa stryjów - przyjął reprezentację strony przeciwnej, więc ci obawiając się przegranej, „[n]aprzód musieli go przyznać rodzonym synowcem, na co dowodów literalnych nie było, choć wszelkie podobieństwo zkądinąd” (I, 48). Maleparta jako mecenas wzbogaca się kosztem swoich klientów (II, 93-94), przejmując ich pretensje i dochodząc ich dla siebie. Takie praktyki ograniczono dopiero w 1768 r. $^{60}$

Wyszukiwanie źródeł wiedzy Kraszewskiego o dawnym Trybunale i jej pożytkowania na kartach powieści można prowadzić jeszcze dalej. Mamy bowiem podanych wiele szczegółów „kuchni” trybunalskiej: zablokowanie przez jedną partię obioru deputata na sejmiku (II, 41), odstępowanie kwater na urzędowe stancje dla deputatów („W dwóch komnatach przyciasnych i dość ciemnych, sklepionych jak wszystkie prawie stare kamienice naszych miast, mieścili się państwo regentowstwo, resztę domu w czasie trybunału wynajmując magistratowi na kwaterę deputacką", I, 77), mamy kwestię zrywania kompletu, które stosowano jako wybieg procesowy, ale na kartach powieści występuje tylko w kontekście deputata Górskiego, który mimo groźby „absentuje się od sądów”, by móc ujrzeć przez okno więzioną żonę Maleparty (I, 107).

58 J. Kitowicz, Opis..., s. 191, 200; H. Kołłątaj, Stan oświecenia..., s. 144.

59 Zob. H. Olszewski, Sejm Rzeczypospolitej epoki oligarchii 1652-1763. Prawo, praktyka, teoria, programy, Poznań 1966, s. 94-95.

60 I. Lewin, Palestra w dawnej Polsce, Lwów 1936, s. 63-64; Volumina Legum, t. 7, Petersburg 1860 , f. 701. 
W tych wszystkich historycznych realiach można znaleźć też drobne błędy - jak choćby informację o tym, że wszystko ożywało w Lublinie na kilka niedziel w roku (I, 18), choć przecież kadencja trybunalska trwała wiele miesięcy. Trzeba jednak uznać, że Kraszewski odwzorował rzeczywistość na tyle, na ile było to możliwe w chwili pisania. Inną sprawą pozostaje, czy taki obraz jest prawdziwy. Nie chodzi tylko o to, że dziś dzięki kolejnym źródłom i badaniom znamy więcej szczegółów, ale o to, czy w istocie tak źle wyglądało dawne sądownictwo, sędziowie, palestra. Źródła takie jak pamiętniki przynoszą przede wszystkim opisy wynaturzeń, a nie kwestii dla piszącego oczywistych. Dlatego też należy podejść do realiów Maleparty z dystansem - powieść jest o tyle realistyczna, że z dawnej rzeczywistości sądowej wzięła tylko to, co złe. Abstrahując od zachowań głównego bohatera, lubelski trybunał na kartach powieści pracuje w cieniu pijaństwa i korupcji. O pijaństwie Kraszewski przypomina wielokrotnie i w różnych kontekstach. Piją wszyscy - mamy „czerwononosych” mecenasów (I, 11), deputatów ucztujących (I, 108) czy upijanych dla przekupstwa (II, 79), a w szynku biesiadują pozostałe osoby związane z sądownictwem: „panowie woźni, posługacze sądowi, skrybenci i hałastra trybunalska” (I, 34). Natomiast przekupić można nie tylko deputatów, ale i wywołujących sprawy instygatora $z$ woźnym czy mecenasa reprezentującego stronę przeciwną (II, 41).

Należy też zastanowić się nad tym, czy Kraszewski sięgał jedynie do pamiętników, a nie do Pamiątek Soplicy, z którymi miał polemizować. Jak już wcześniej wspomniano, w Maleparcie przedstawiono zbliżone motywy, choć zrobiono to w odmienny sposób. Jedna z gawęd Rzewuskiego - Trybunał lubelski - poświęcona jest w całości procesowaniu się w tym sądzie ${ }^{61}$, choć opisuje już realia czasów stanisławowskich (mamy tam mundury wojewódzkie wprowadzone w 1776 r., a wymieniony jako marszałek Ignacy Myszka Chołoniewski, starosta kołomyjski, rzeczywiście pełnił ten urząd w 1777 r., choć prezydentem nie był wówczas - wymieniony przez Rzewuskiego - kanonik Wodzicki ${ }^{62}$ ). Mamy, tak jak później u Kraszewskiego, pijatyki i przekupstwo, adwokatów na konferencji i palestrę w kole walczącą na szable, wreszcie szczegóły odbywanego sądownictwa - tłum wokół trybunału, procesyjne wejście marszałka, deputatów i palestry, a przy prowadzonych sprawach niegodziwości adwokatów czy nawet wdowę odzieraną z majątku.

Poza Pamiątkami Soplicy trudno jednak doszukiwać się dalszych współczesnych zapożyczeń literackich, bo Rzewuski zapoczątkował nurt szlacheckiej gawędy, który dopiero co znalazł naśladowców i zaczynał się w kolejnych latach rozwijać. Bardziej interesujące mogłoby być poszukiwanie tych samych motywów w innych utworach Kraszewskiego - na ile są one „historyczne” (związane z konkretną epoką), a na ile pisarz traktuje je jako uniwersalne. Maleparte poprzedziła

61 H. Rzewuski, Pamiq̨tki..., s. 99-125.

62 Deputaci Trybunału Koronnego 1578-1794. Spis, cz. V: 1751-1794, opr. J. Ternes, Warszawa 2017, s. 213. 
choćby Latarnia czarnoksięska, powieść współczesna, ale znajdziemy tam zarówno przebiegłego jurystę o dwuznacznej moralności, staruszka z gatunku tych, „co nowicjat przy trybunale jeszcze lubelskim odprawili i pamiętali świetne czasy palestry", jak i szlacheckie życie ponad stan, które dosadnie pokazane jest przy okazji późniejszych przygód eksmecenasa Paprockiego ${ }^{63}$.

\section{Wnioski}

Zarówno staropolska palestra, jak i sędziowie nie cieszyli się dobrą opinią współczesnych, co znalazło potem odbicie w literaturze okresu porozbiorowego ${ }^{64}$. W tych kategoriach należy też spojrzeć na utwór Kraszewskiego. Główny bohater to przesiąknięty złem mecenas, stosujący typowe dla dawnej palestry sztuczki i uosabiający najgorsze przywary dawnych prawników. W ocenie powieści dominuje przeświadczenie, że większość postaci zarysowana jest negatywnie, a to ze względu na sprzeciw wobec idealizującej dawne czasy postawy Rzewuskiego ${ }^{65}$. Choć na tle tytułowego Maleparty niektórzy adwokaci lubelscy pokazani są w sposób jeśli nie pozytywny, to przynajmniej pobłażliwy, są to jednak wyjątki. Podobnie jest z deputatami, wśród których ukazano tylko dwie nieprzekupne osoby.

Wypada zgodzić się z opinią, że powieści historyczne są mało interesujące ze źródłoznawczego punktu widzenia, bo dostarczają one nie materiału o przeszłości, a o autorze i jego wiedzy. Ciekawe jest za to badanie zgodności fabuły z dokumentowaną przeszłością ${ }^{66}$. W przypadku Maleparty - jak wyżej zanalizowano - widać gruntowne oparcie się na dostępnych wówczas źródłach, które służyły do budowy tła opowieści. Choć realistycznie odtworzono sądownictwo trybunalskie, to jednak trudno jednoznacznie stwierdzić, czy mecenas Jan Aleksander Paprocki rzeczywiście istniał. Niewątpliwie jednak jego działania przedstawione na kartach książki oddają znane grzechy dawnej palestry. Postać Maleparty przytłacza nielicznych bohaterów pozytywnych, tak jak przedstawione szczegóły funkcjonowania sądownictwa podkreślają przede wszystkim to, co było w nim złe - jak pijaństwo czy korupcja. W tym zakresie powieść Kraszewskiego jest więc zaprzeczeniem apoteozy przeszłości, która pojawiała się wówczas w nurcie literatury sarmackiej.

63 J.I. Kraszewski, Latarnia czarnoksięska. Obrazy naszych czasów, Lwów-Warszawa 1872, t. II, s. 19-20; t. III, s. 15.

64 Zob. A. Redzik, T.J. Kotliński, Historia adwokatury, Warszawa 2018, s. 67-71.

65 P. Chmielowski, Józef Ignacy Kraszewski..., s. 168-169.

66 Z. Wojtkowiak, Nauki pomocnicze historii najnowszej. Źródłoznawstwo. Źródła narracyjne, cz. 1: Pamiętnik, tekst literacki, Poznań 2003, s. 149-150. 
Trzeba także zauważyć, że poza przeprowadzoną tu analizą dzieła ważne jest też coś innego - jako że Kraszewski był pionierem powieści historycznej, swoją twórczością wywierał różnoraki wpływ na późniejszych autorów. To właśnie on należał do pierwszych, którzy przenieśli do beletrystyki opinie o dawnych jurystach ze źródeł i pamiętników - tym samym powielając i utrwalając negatywny obraz dawnego sądownictwa oraz tworzących go sędziów (deputatów) i palestry. W dodatku, choć Kraszewski opisywał realia saskie, wskutek dotychczasowych błędnych interpretacji obraz ten przypisywano epoce następnej, podczas gdy w reformującej się Rzeczypospolitej wiele nieprawidłowości udało się wyeliminować.

\section{Bibliografia}

Bachórz J., Jak się dawniej „fizjologie" pisały, czyli Mecenas (Dawny Palestrant) Józefa Ignacego Kraszewskiego, [w:] Nowela, opowiadanie, gawęda. Interpretacje małych form narracyjnych, red. K. Bartoszyński, M. Jasińska-Wojtkowska, S. Sawicki, Państwowe Wydawnictwo Naukowe, Warszawa 1979.

Bachórz J., Józef Ignacy Kraszewski, [w:] Literatura krajowa w okresie romantyzmu 1831-1863, t. III, red. M. Janion, M. Maciejewski, M. Gumkowski, Instytut Badań Literackich, Warszawa 1992.

Bar A., Charakterystyka i źródta powieści Kraszewskiego w latach 1830-1850, Kasa im. J. Mianowskiego, Warszawa [ok. 1923].

Batorowska H., Jan Nepomucen Bobrowicz: polski wydawca i ksiegarz w Saksonii w czasach Wielkiej Emigracji, Wydawnictwo Naukowe WSP, Kraków 1992.

Budrewicz T., Biografie Kraszewskiego i ich potencjał legendotwórczy, [w:] O Kraszewskim. Studia, Wydawnictwo Naukowe Uniwersytetu Pedagogicznego, Kraków 2013.

Chmielowski P., Józef Ignacy Kraszewski. Zarys historyczno-literacki, G. Gebethner i S-ka, Kraków 1888.

Danek W., Józef Ignacy Kraszewski, Wiedza Powszechna, Warszawa 1973.

Danek W., Kraszewski i Walter Scott, „Rocznik Naukowo-Dydaktyczny WSP w Krakowie. Prace historyczno-literackie" 1963, z. 17, s. 3-15.

Danek W., Powieści historyczne J. I. Kraszewskiego, Ludowa Spółdzielnia Wydawnicza, Warszawa 1966.

Deputaci Trybunału Koronnego 1578-1794. Spis, cz. V: 1751-1794, opr. J. Ternes, Wydawnictwo Sejmowe, Warszawa 2017.

Fronczek Z.W., Lubelska historia nikczemności. Encyklopedia legend, sensacji i anegdot Lublina, Polihymnia, Lublin 2009.

Gierowski J., Lubomirski Jerzy Aleksander, [w:] „PSB”, t. 18, Wydawnictwo Zakładu Narodowego im. Ossolińskich, Wrocław-Warszawa-Kraków-Gdańsk 1973.

Gombin K., Trybunat koronny. Ceremoniat i sztuka, Wydawnictwo Katolickiego Uniwersytetu Lubelskiego, Lublin 2013. 
Grabowski M., Michała Grabowskiego listy literackie, wyd. A. Bar, Polska Akademia Umiejętności, Kraków 1934.

Hahn W., Lublin w twórczości Józefa Ignacego Kraszewskiego, Lubelski Komitet Obchodu Setnej Rocznicy Zgonu St. Staszica, Lublin 1925.

Jarowiecki J., Powieści historyczne Ignacego Kraszewskiego (geneza i klasyfikacja), „Rocznik Naukowo-Dydaktyczny Studium Terenowego Krakowskiej WSP w Tarnowie. Nauki humanistyczne" 1961, z. 1, s. 143-177.

Jarowiecki J., Źródła powieści historycznych Józefa Ignacego Kraszewskiego o czasach stanisławowskich, „Rocznik Naukowo-Dydaktyczny WSP w Krakowie. Prace historyczno-literackie" 1963, z. 17, s. 33-61.

Kermisz J., Lublin i lubelskie w ostatnich latach Rzeczypospolitej, t. 1: W czasie Sejmu Wielkiego i wojny polsko-rosyjskiej 1792 r. oraz pod rzadami targowicko-grodzieńskimi, Wydawnictwo Zarządu Miejskiego, Lublin 1939.

Kitowicz J., Opis obyczajów za panowania Augusta III, t. 1, opr. R. Pollak, Zakład Narodowy im. Ossolińskich - De Agostini Polska, Wrocław-Warszawa 2003.

Kitowicz J., Pamiętniki, czyli Historia polska, opr. P. Matuszewska, Państwowy Instytut Wydawniczy, Warszawa 1971.

Kołłątaj H., Stan oświecenia w Polsce w ostatnich latach panowania Augusta III (1750-1764), opr. J. Hulewicz, Zakład Narodowy im. Ossolińskich - De Agostini Polska, WrocławWarszawa 2003.

Korespondencja Józefa Ignacego Kraszewskiego. Seria III: Listy z lat 1844-1862, t. 9, k. 504 (BJ rkps 6468 IV).

Krasicki I., Mikołaja Doświadczyńskiego przypadki, wstęp B. Gubrynowicz, Zakład Narodowy im. Ossolińskich - De Agostini Polska, Wrocław-Warszawa 2005.

Kraszewski J.I., Krasicki. Życie i dzieła. Kartka z dziejów literatury XVIII wieku, Gebethner i Wolff, Warszawa 1879.

Kraszewski J.I., Latarnia czarnoksięska. Obrazy naszych czasów, Księgarnia Gubrynowicza i Schmidta - Księgarnia Michała Glückberga, Lwów-Warszawa 1872, t. II-III.

Kraszewski J.I., Maleparta. Powieść historyczna z XVIII w., Księgarnia Gubrynowicza i Schmidta - Księgarnia Michała Glückberga, Lwów-Warszawa 1874, t. I-IV.

Kraszewski J.I., Pamiętniki, opr. W. Danek, Ossolineum - De Agostini Polska, WrocławWarszawa 2005.

Kraszewski K., Monografija domu Kraszewskich vel Kraszowskich Jastrzębczyków: z herbarzy, kronik, dokumentów i papierów familijnych, Poznań 1861.

Kronika literacka, „Biblioteka Warszawska” 1844, t. 4, s. 210-218.

Lewin I., Palestra $w$ dawnej Polsce, Redakcja Pamiętnika Historyczno-Prawnego, Lwów 1936.

Łoś W., Ostatni podkomorzy lubelski, „Przewodnik Naukowy i Literacki” 1891, nr 6, s. $530-536$.

Malik J., Miasto dwóch miast. Wokół powieści Józefa Ignacego Kraszewskiego „Maleparta”. Dopowiedzenia, [w:] Europejskość i rodzimość. Horyzonty twórczości Józefa Ignacego Kraszewskiego, red. W. Ratajczak, T. Sobieraj, Wydawnictwo Poznańskiego Towarzystwa Przyjaciół Nauk, Poznań 2006.

Maliszewski E., Bibljografja pamiętników polskich i Polski dotyczących (druki i rękopisy), Towarzystwo Miłośników Historii, Warszawa 1928. 
Maternicki J., Kultura i edukacja historyczna społeczeństwa polskiego w XIX w. Zarys problematyki i postulaty badawcze, [w:] Edukacja historyczna społeczeństwa polskiego w XIX w. Zbiór studiów, red. J. Maternicki, Państwowe Wydawnictwo Naukowe, Warszawa 1981.

Ochocki J.D., Pamiętniki Jana Duklana Ochockiego z pozostałych po nim rękopismów przepisane i wydane, t. 1-4, opr. J.I. Kraszewski, nakładem Józefa Zawadzkiego, Wilno 1857.

O kilku dziełach z lekkiego piśmiennictwa w ostatnich czasach, „Przegląd Poznański” 1845, t. I, s. 56-63.

Olszewski H., Sejm Rzeczypospolitej epoki oligarchii 1652-1763. Prawo, praktyka, teoria, programy, Uniwersytet im. Adama Mickiewicza, Poznań 1966.

Pawlik M., Katalog księgozbioru, rękopisów, dyplomów, rycin, map, atlasów, fotografji, jakoteż osobistych dyplomów, adresów itp. pozostałych po śp. Józefie Ignacym Kraszewskim, Nakładem rodziny zmarłego, Lwów 1888.

Pilarczyk P.M., Doświadczyński przed Trybunałem. Twórczość Ignacego Krasickiego w świetle historii prawa, „Pamiętnik Literacki” 2017, nr 3, s. 90-96.

Rawita Gawroński F., Kilka słów o Autorze i jego pamiętnikach, [w:] A. Andrzejowski, Ramoty starego Detiuka o Wołyniu, t. I, Księgarnia Stowarzyszenia Nauczycielstwa Polskiego, Wilno 1921.

Redzik A., Kotliński T.J., Historia adwokatury, Naczelna Rada Adwokacka - Redakcja „Palestry", Warszawa 2018.

Riabinin J., Rada miejska lubelska w XVIII w., Magistrat Miasta Lublina, Lublin 1933.

Rzewuski H., Pamiątki Soplicy, opr. Z. Szweykowski, Zakład Narodowy im. Ossolińskich - De Agostini Polska, Wrocław-Warszawa 2004.

Smoleński W., Czasy Stanisława Augusta w powieściach J. I. Kraszewskiego, [w:] Książka jubileuszowa dla uczczenia pięćdziesięcioletniej działalności literackiej J. I. Kraszewskiego, [s.n.] Warszawa 1880.

Śliwina W.J., Legendy i opowiadania lubelskie, http://www.biblioteka.teatrnn.pl/dlibra/ dlibra/docmetadata?id=9237\&from=publication (dostęp: 1.07.2020).

Śliwina W.J., Podanie o Maleparcie, [w:] Podania i legendy Lublina, opr. A. Wójcikowski, W. Wójcikowski, Towarzystwo Miłośników Lublina, Lublin 2001.

Twardowski S., Satyr na twarz Rzeczypospolitej w roku 1640, Wydawnictwo Uniwersytetu Marii Curie-Skłodowskiej, Lublin 2007.

Tyrowicz M., Ochocki Jan Duklan Modest, [w:] „PSB”, t. 23, Wydawnictwo Zakładu Narodowego im. Ossolińskich, Wrocław-Warszawa-Kraków-Gdańsk 1978.

Volumina Legum, t. 7, wyd. J. Ohryzko, Petersburg 1860.

Wierzbicka-Michalska K., Moszyński August Fryderyk, [w:] „PSB”, t. 22, Wydawnictwo Zakładu Narodowego im. Ossolińskich, Wrocław-Warszawa-Kraków-Gdańsk 1978.

Wierzbicki A., Historiografia polska doby romantyzmu, Funna, Wrocław 1999.

Wojtkowiak Z., Nauki pomocnicze historii najnowszej. Źródłoznawstwo. Źródła narracyjne, cz. 1: Pamiętnik, tekst literacki, Wydawnictwo Poznańskie, Poznań 2003.

Wybicki J., Pamiętniki Józefa Wybickiego, senatora wojewody Królestwa Polskiego, t. 1, wyd. E. Raczyński, Księgarnia i Drukarnia W. Stefańskiego, Poznań 1840. 